\section{Zone Refining Demonstrated at the Transition Between Two Solid Phases}

\author{
Arnold Lundén, Erik Svantesson and Henry Svensson \\ Department of Physics, Chalmers Institute of Technology, \\ Göteborg \\ (Z. Naturforschg. 20 a, 739-740 [1965]; received 29 March 1965)
}

The feasibility of solid zoning has been demonstrated for a binary mixture of lithium and silver sulfates. After one zone pass at a rate of $0.44 \mathrm{~mm} /$ hour the first part of the ingot was nearly pure $\mathrm{Li}_{2} \mathrm{SO}_{4}$ while $\mathrm{Ag}_{2} \mathrm{SO}_{4}$ was enriched in its end part.

The possibility to apply zone refining to solid-solid transformations was considered already by PFANN ${ }^{1}$, but to our knowledge no experimental results have been reported, although a patent describes a purification method where the zone is in a plastic state just below the melting point ${ }^{2}$. The reason for the low number of applications in solids is of course that two basic conditions must be fulfilled for all zone refining processes $^{1}$, namely that the two phases in question must differ in solute concentration at equilibrium, and that the diffusivity of solute must be substantially greater in the phase that comprises the zone. While this second requirement is nearly always fulfilled for liquid-solid transitions, this is usually not so in solid-solid transitions. However, some salts have high temperature modifications where both basic conditions are fulfilled, and solid zoning thus should be feasible. Thus the cation self-diffusion coefficient exceeds $10^{-5} \mathrm{~cm}^{2} \mathrm{~s}^{-1}$ in pure $\alpha-\mathrm{Li}_{2} \mathrm{SO}_{4}$ (l. c. ${ }^{3}$ ), and from transference experiments it is found for lithium-rich $\mathrm{Li}_{2} \mathrm{SO}_{4}-\mathrm{Ag}_{2} \mathrm{SO}_{4}$ mixtures, that the mobility of $\mathrm{Ag}^{+}$exceeds that of $\mathrm{Li}^{+}$ ions ${ }^{4,5}$. The transition between $\alpha$ and $\beta$ phases occurs at $575{ }^{\circ} \mathrm{C}$ for pure $\mathrm{Li}_{2} \mathrm{SO}_{4}$ and at $515{ }^{\circ} \mathrm{C}$ for the eutectiod with 20 mole $\% \mathrm{Ag}_{2} \mathrm{SO}_{4}$ (l. c. ${ }^{4}$ ).

An ingot of the original composition of about 8.2 mole $\% \mathrm{Ag}_{2} \mathrm{SO}_{4}$ was traversed by an $\alpha$-phase zone (zone length about $7 \mathrm{~mm}$ ) at a rate of $0.44 \mathrm{~mm} /$ hour ${ }^{6}$. After a single pass the ingot was sliced into samples for which $\mathrm{Li}$ was determined by flame spectrophotometry, $\mathrm{Ag}$ as $\mathrm{AgCl}$, and the anion as $\mathrm{BaSO}_{4}$. The results are shown in Fig. 1, where the percentage has been calculated from the $\mathrm{AgCl}$ and $\mathrm{BaSO}_{4}$ determinations, except for the very first part of the ingot, where the amount of $\mathrm{Ag}^{+}$was too small to be determined by the procedure used for the other samples. Estimated

1 W. G. Pfand, Zone Melting, John Wiley \& Sons, New York 1958, p. 54.

2 German Patent no. 1,004,382 (1957) ; see Chem. Abstr. 54, $14082 \mathrm{~g}[1960]$.

3 A. LundÉn, Z. Naturforschg. 17 a, 142 [1962].

4 H. A. ØуЕ, Acta Chem. Scand. 18,361 [1964]; Thesis Trondheim 1963.

5 V. Lunbimov and A. Lundén, to be published.

- Details of the experimental arrangement will be published in connection with a study of isotope effects detectable by zone refining of pure lithium sulfate.

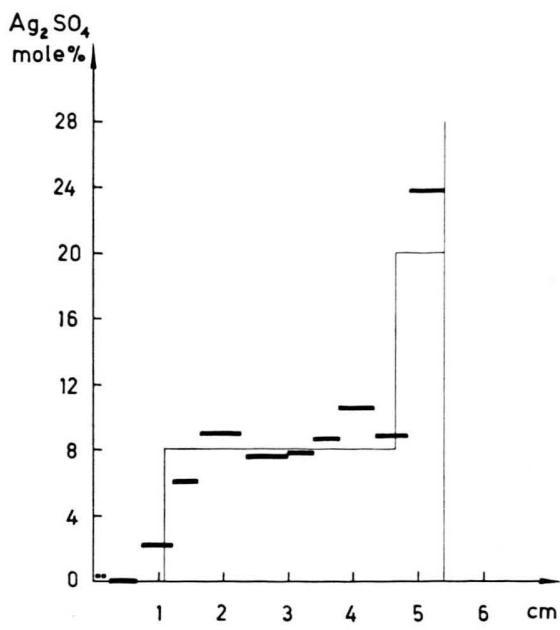

Fig. 1. Distribution of silver sulfate in a $54 \mathrm{~mm}$ long ingot after a single zone pass at a rate of $0.44 \mathrm{~mm} /$ hour. Thin line shows the ideal distribution, while thick lines give the results of the chemical analysis. The dotted line indicates that traces of siīver sulfate were present.

amounts are shown as a dashed line for these samples. A theoretical distribution is shown for the assumption that pure $\beta-\mathrm{Li}_{2} \mathrm{SO}_{4}$ is obtained until the zone has reached the eutectoid composition. This latter composition is to be expected for the last zone length, while for the intermediate region stratified layers of pure $\mathrm{Li}_{2} \mathrm{SO}_{4}$ and of a $\mathrm{Ag}_{2} \mathrm{SO}_{4}$ rich mixture might be expected, giving the original composition as an average ${ }^{7}$. The degree of agreement between the obtained and the ideal distribution is acceptable, although some of the samples show larger deviations than expected from the accuracy of the chemical analysis ${ }^{8}$, and the fluctuations in the distribution should be considered as a reality.

If an appreciable separation is to be obtained by solid zoning, the rate of zone travel should not exceed $D / l$, where $D$ is the diffusion coefficient and $l$ the zone length ${ }^{1}$. However, we also made an experiment with a considerably higher rate, $2.3 \mathrm{~mm} /$ hour. For the extreme ends, samples with a length of about $2 \mathrm{~mm}$, the $\mathrm{Ag}_{2} \mathrm{SO}_{4}$ concentration was 0.3 and 20.6 mole $\%$ respectively, while for the main part of the ingot there were

7 The transition temperature at the front of the zone remains constant, about $546^{\circ} \mathrm{C}$, throughout the whole experiment, while the transition temperature at the rear of the zone gradually decreases to about $515{ }^{\circ} \mathrm{C}$ corresponding to the eutectoid composition. Thus the zone length, initially about $7 \mathrm{~mm}$, increases somewhat during the first part of the experiment.

8 For most sample- the analysis was duplicated, and the 95\% confidence limits of the standard deviation $\sigma$ (in per cent of the mean value) were estimated as $0.26<\sigma<0.81$ for the $\mathrm{Ag}$ and $0.62<\sigma<1.34$ for the $\mathrm{SO}_{4}$ determination, cf. A. Hald, Statistical Theory with Engineering Applications, J. Wiley \& Sons, New York 1952, p. 289. 
large fluctuations between adjacent samples, the limits for the $\mathrm{Ag}_{2} \mathrm{SO}_{4}$ content being 5.4 and 13.5 mole $\%{ }^{9}$.

The results reported here prove that solid zoning can be used as a method of purification. Although the number of possible applications is limited, because most solid systems do not fulfill the condition regarding the diffusion coefficient, the method might still be

9 The samples were somewhat smaller than in the low-rate experiment, and the $95 \%$ confidence limits are $0.87<\sigma$ $<2.32$ for the $\mathrm{Ag}$ and $0.95<\sigma<2.51$ for the $\mathrm{SO}_{4}$ determination. In spite of the standard deviation being higher, of value, since it offers a posibility to do zone refining at a temperature far below the melting point of the substance.

This investigation is supported by the Swedish Technical Research Council. We acknowledge the assistance of Mrs. L. JANSEN with the chemical analysis.

it is obvious that the fluctuations between adjacent samples were much larger in the experiment at a rather high rate, than in the first experiment.

\section{Spikefreie Emission eines kontinuierlichen Rubinlasers}

\section{K. GürRs}

Forschungslaboratorium der Siemens \& Halske AG, München (Z. Naturforschg. 20 a, 740-741 [1965]; eingegangen am 12. April 1965)

In Fortführung der Arbeiten über das Schwingungsverhalten des Rubinlasers ist es gelungen, einen Rubinlaser bei Kühlung mit flüssigem Stickstoff spikefrei kontinuierlich zu betreiben. Wesentlich für die Ausdämpfung der Relaxationsimpulse (Spikes) - gegenüber den früheren Ergebnissen von NeLsov und Boyle ${ }^{1}$ - ist die hohe Dotierung der Rubine (bis 0,04\% Chrom), die Verwendung von langen Kristallen (57 mm) mit sphärischen „fast“ konfokalen Spiegeln und eine günstige Symmetrie der Pumplichteinstrahlung.

In den früheren Arbeiten ${ }^{2 a-e}$ konnte bereits für den Impulslaser gezeigt werden, da $\beta$ sich unter bestimmten Bedingungen eine Emission ohne Spikes ergibt. Eine solche erhält man durch geeignete Wahl der Abmessungen des Lasers und der Arbeitsbedingungen. Günstige Bedingungen ${ }^{2}$ für ein Ausdämpfen der Relaxationsimpulse sind

1. geringe Resonatorverluste pro Durchgang,

2. große Resonatorlänge (also insgesamt geringe Verluste pro Zeiteinheit, d. h. große Resonatorgüte),

3. große Pumpleistung,

4. hohe Dotierung,

5. Kühlung des Kristalls auf tiefe Temperaturen ${ }^{3}$ (das Produkt $\tau \cdot \Delta v$ aus Lebensdauer und Linienbreite wird dadurch kleiner) und

6. Verwendung von sphärischen Spiegeln in "fast" konfokaler Anordnung.

1 D. F. Nelson u. W. S. Boyle, Appl. Opt. 1, 181 [1962].

$2{ }^{\mathrm{a}}$ K. Gürs, Z. Naturforschg. 17 a, 991 [1962]; ${ }^{\mathrm{b}}$ Z. Naturforschg. 18 a, 418 [1963]; ${ }^{c}$ Proc. 3rd Intern. Symp. on Quantum Electronics, Paris 1963, S. 1113; ${ }^{\mathrm{d}} \mathrm{Z}$. Naturforschg. 18 a, 1363 [1963]; ${ }^{e}$ Proc. Intern. Symp. on Laser
Diese Bedingungen gelten natürlich auch für den Dauerbetrieb, sie sind dabei allerdings zum Teil schwer zu erfüllen. Wir erinnern z. B. an die geringe Dotierung der "Trompete“, die bei dem bisher einzigen mit flüssigem "Stickstoff gekühlten kontinuierlichen Rubinlaser von NeLson und Boyle ${ }^{1}$ als Kristall verwendet wurde. Die Trompete bestand aus einem 11,5 mm langen Rubinteil mit $0,006 \%$ Chromdotierung und einem sich kegelförmig erweiternden Saphirteil. Das Pumplicht wurde durch die Kegelbasis hindurch an dem einen Laserspiegel vorbei eingestrahlt und durch Totalreflexion im Kristall gehalten.

Die genannte Bedingung 4 einer hohen Dotierung bedeutet nun, daß das Pumplicht im Kristall bereits über kleine Strecken absorbiert wird. Der Kristall kann also nicht wie die „Trompete“ in Längsrichtung (von einem Ende her) gepumpt werden. Vielmehr muß man das Pumplicht durch die Mantelfläche der Kristalle hindurch einstrahlen, d. h. man muß auf stabförmige Lampen (und elliptische Reflektoren) zurückgreifen.

Die Frage war nun, ob diese Lampen die erforderliche Leistung abgeben. Eine diesbezügliche Abschätzung gelingt bereits mit Hilfe von Impulsmessungen. Nach diesen Messungen sollte, wie schon früher angegeben ${ }^{2} \mathrm{e}$, der Schwellwert bei $4 \mathrm{~cm}$ langen Rubinkristallen und angepaßter Lampe um etwa den Faktor 3 höher liegen als bei Neodym-dotiertem Calciumwolframat. Da bei diesem Material der Schwellwert für kontinuierlichen Betrieb etwa bei $500 \mathrm{~W}$ liegt, eine $4 \mathrm{~cm}$ lange Quecksilberkapillarlampe jedoch eine Nennleistung bis zu $3200 \mathrm{~W}$ besitzt, sollte also auch für $\mathrm{Ru}$ bine hoher Dotierung ein Dauerbetrieb möglich sein, und zwar bei Pumpleistungen bis zu mehr als dem doppelten Schwellwert.

Im Hinblick auf die Bedingungen 2 und 3 wurden für unsere Experimente relativ lange Kristalle vorgesehen, und zwar passend zu den besonders leistungsfähigen Quecksilberkapillarlampen der Type A 1679

Physics and Applications, Bern, Oktober 1964, Tagungsheft Z. Angew. Math. Phys. 18, 49 [1965].

3 S. Koozekanani, M. Ciftan u. A. Krutchkoff, Appl. Opt. 1, 372 [1962]. 